\title{
LA DESESPERACIÓN DEL ARTISTA. EL ULTRAÍSMO EN LAS CARTAS CRUZADAS DE HUIDOBRO, GUILLERMO DE TORRE Y GERARDO DIEGO
}

\author{
Miguel Ángel García \\ Universidad de Granada \\ Granada, España \\ garciaga@ugr.es
}

\section{RESUMEN / ABSTRACT}

Las cartas que intercambian Huidobro, Torre y Diego muestran distintas imágenes del ultraísmo: Huidobro es crucial para su constitución, pero cuando surge la polémica con Reverdy acaba rompiendo con los representantes de esta primera vanguardia española; Torre lo considera un movimiento integrador de todas las tendencias nuevas y defiende su voluntad de ir más allá; Diego, en fin, descubre la poesía nueva con Ultra pero pronto se convierte en creacionista y guarda fidelidad a Huidobro. La correspondencia cruzada de estos tres autores aporta materiales de gran interés para iluminar este complejo entramado de relaciones y descubrir nuevas facetas del ultraísmo cuando se cumplen cien años de la segunda y decisiva llegada del chileno a España.

Palabras ClaVe: Vicente Huidobro, Guillermo de Torre, Gerardo Diego, epistolario, ultraísmo.

THE ARTIST'S DESPERATION. ULTRAISM IN THE CROSS LETTERS OF HUIDOBRO, GUILLERMO DE TORRE AND GERARDO DIEGO

Huidobro, Torre and Diego exchange some letters that show different pictures of ultraism: Huidobro is crucial for its constitution, but when controversy arises with Reverdy, he breaks with the representatives of this first Spanish avant-garde. Torre believes that is an integrating movement of all new trends and he defends his willingness to go beyond. Finally, Diego discovers new poetry with Ultra, but soon he becomes a creationist and he maintains fidelity to Huidobro. The cross correspondence of these authors provides materials of great interest in order to illuminate these complex relationships and discover new facets of ultraism, when one hundred years have passed since the second and decisive arrival of the Chilean to Spain. 
KEYWORDS: Vicente Huidobro, Guillermo de Torre, Gerardo Diego, correspondence, ultraism.

\section{PROPÓSITO}

Se cumplen cien años de la segunda llegada de Huidobro a España, decisiva para el arranque del ultraísmo ${ }^{1}$. Cansinos Assens, animador de esta auroral vanguardia española entre la juventud atenta a las novedades, escribe en el primer número de Cosmópolis, en enero de 1919, que la visita del chileno ha sido el acontecimiento supremo del año literario de 1918 e incluso que Huidobro ha venido a descubrir la senectud del ciclo novecentista, lo mismo que Rubén Darío vino con anterioridad a acabar con el romanticismo². El tránsito del autor de Horizon carré, sigue diciendo, ha renovado la cronología literaria y señala lo único reseñable de ese año en los monótonos anales de las letras españolas, sobre todo de la poesía, narcotizada de misoneísmo (Anderson 320). Huidobro ha representado -afirmará ya en junio de 1919, en la revista Cervantes - un documento personal, un evangelio vivo cuando la guerra terminaba y era preciso renovarse, aunque advierte de inmediato que Ultra no ha de confundirse con ninguna escuela parcial de las que han florecido últimamente en Francia, ni siquiera con el "creacionismo de Reverdy y Huidobro", ya que supone un movimiento autóctono realizado por jóvenes, muchos de los cuales no han leído al chileno ${ }^{3}$. Con este dar y quitar importancia al poeta de Tour Eiffel en los orígenes de la vanguardia española, Cansinos estaba sembrando los vientos que traerían poco después la tempestad de la enconada disputa entre ultraístas y creacionistas, que no es sino una consecuencia de la polémica entre el creacionismo de Huidobro y el cubismo de Reverdy.

La presencia del poeta chileno en España y su influencia entre los jóvenes vanguardistas españoles están bien estudiadas. Remitimos a los trabajos de Morelli ("Huidobro"), Valcárcel y Goic.

2 Se hacen eco de estos juicios Costa, "Del modernismo" 263; Díaz de Guereñu, "Ultraístas" 164; Bernal Salgado, "Poesía" 163.

3 Para este aspecto: Fuentes Florido 38; Díaz de Guereñu, "Ultraístas" 160; Alcantud 217. 
Puede ser revelador analizar, con motivo del centenario del ultraísmo, el epistolario que Huidobro cruza con dos jóvenes vanguardistas españoles, el ultraísta Guillermo de Torre y el inicialmente ultraísta pero enseguida creacionista Gerardo Diego, así como las cartas que se dirigen estos últimos, donde también encontramos visiones distintas de lo que había de ser, en el sentir de cada uno, la vanguardia histórica en España. El intercambio epistolar entre estos tres autores constituye una pieza del efecto coral o la polifonía (Bernal Salgado, "Creacionismo epistolar" 25) a la que también contribuyen otras correspondencias decisivas para el estudio del vanguardismo hispánico y que han sido recopiladas y publicadas en los últimos años, como la de Huidobro y Larrea (Morelli, "Introducción"), la de Diego y Larrea (Díaz de Guereñu y Bernal Salgado) o la de Cansinos y Guillermo de Torre (García, Rafael Cansinos). Los tres corresponsales escogidos hacen valoraciones sobre el movimiento ultraísta que oscilan entre el desprecio (en el caso de Huidobro), la defensa (Torre lo enlaza con las corrientes europeas de vanguardia, en particular con el cubismo, que le sirve para saltar en segunda instancia, tras la presentación de los obligados respetos al chileno, por encima del creacionismo) y la heterodoxia (Diego abandona a no mucho tardar las filas ultraístas seducido por la mayor coherencia de la estética creacionista y la calidad poética de Huidobro).

Las cartas a tres bandas que nos proponemos revisar dan cuenta de este complejo entramado y del lugar que en él ocupa Ultra, un movimiento que quiere ir más allá del ismo (Urrutia 89) y que se caracteriza, como tantas veces se ha dicho, por una indefinición estructural, por su apertura a todas las corrientes nuevas sin distinción y por la falta de una teoría poética sólida, a diferencia del creacionismo huidobriano ${ }^{4}$. En el mencionado artículo de junio de 1919, "Los poetas del Ultra", Cansinos deja meridianamente claro que ese lema, "más allá", señala un movimiento literario, no una escuela, y que representa el compromiso de ir avanzando siempre con el tiempo (Videla 91; Fuentes Florido 37). Por su parte, el Torre de Literaturas europeas de vanguardia (1925) - un libro que Jarnés, componente de la llamada a partir de 1924 "joven literatura", considera la "triste monografía del ultraísmo español" (Díaz de Guereñu, "Ultraístas" 157; Bonet, "Baedeker" 50), ya que en efecto puede verse como su acta de defunción (Bonet, Las cosas 506;

4 Así lo señalan Díaz de Guereñu, "Ultraístas" 159-163; Pérez Bazo, "El ultraísmo" 101; Aullón de Haro 187-195; Bonet, Las cosas 12. 
Alcantud 427) - afirma que este movimiento aspira a condensar en su haz genérico una pluralidad de direcciones, y de aquí que constituya un "vértice de fusión potente" adonde afluyen todas las tendencias vanguardistas (Torre, Literaturas 37; Videla 93). Más contundente, uno de esos poetas del Ultra, José Rivas Panedas, sentencia en septiembre de 1919, también en Cervantes, que el creacionismo es una cosa muy concreta al lado del ultraísmo, el cual no es un dogma ni un modo, mientras que el creacionismo sí ${ }^{5}$. En el deslinde de ultraísmo y creacionismo, que no ha dejado de verse como espinoso (Martínez Ferrer 9), el primero es catalogado por los ultraístas como un movimiento abierto a todo lo nuevo y el segundo como una escuela cerrada. Muy distinta resulta sin embargo, como aquí mostraremos, la visión de Huidobro y de su seguidor Gerardo Diego.

\section{HUIDOBRO, UN EVANGELIO VIVO}

El 28 de diciembre de 1918, Torre escribe a Huidobro explicándole que, tras la partida de este, sus "afines" españoles se han quedado nostálgicos y se ha ido cristalizando en ellos "la evocación estatuaria de su figura lírica, exornada de halos sugerentes" (Huidobro 3). Con la lejanía del maestro y modelo, los discípulos han percibido desoladamente "cómo en el estanque literario madrileño emergía nuevamente la inerte linfa verdinegra, y cómo las trepidantes ondas concéntricas que usted ha logrado distender se constreñían tímidas en un reconcentramiento de mortuorio estatismo" (4). El estilo de Torre, hasta este punto más bien modernista, se hace vanguardista a continuación y adquiere ese aire inconfundible suyo: los jóvenes del Ultra portan "los frutecidos motivos germinales de sus directrices Poemas árticos, de su cósmico Ecuatorial y de su emotiva Tour Eiffel", los tres libros que, junto a Hallali y la supuesta segunda edición de El espejo de agua (Anderson 281, 295) que el propio Torre (Ultraísmo 51) juzgará más tarde una impostura o mixtificación, el chileno publica en Madrid en 1918. Se suman a ellos "las irradiaciones de afines espíritus galos con quienes usted nos hizo intimar y a los que vamos desglosando pausadamente" (Huidobro 4). Torre hace explícito el nombre de Apollinaire, a quien ha dedicado una elegía rechazada en varias revistas, pero lo importante es que este dibujo de Huidobro como iniciador de los jóvenes 
ultraístas en "afines espíritus" de la vanguardia francesa, esencialmente los cubistas, va a convertirse, como la ya vista alusión de Cansinos a Reverdy, en motivo clave de la controversia entre el chileno y sus admiradores españoles.

Precisamente, Torre le envía con esta carta dos artículos de los siete que, entre noviembre y diciembre de 1918, Cansinos ha consagrado en La Correspondencia de España a las nuevas orientaciones líricas (Anderson 316319) y donde ha abordado, conforme aquel adelanta a su corresponsal, ciertos puntos del creacionismo como su correlación con los "alardes cubistas" de la pintura nueva (Huidobro 5). A vuelta de correo, en marzo de 1919, Huidobro acusa recibo desde Santiago de Chile de los artículos de Cansinos y comenta a renglón seguido que la "batalla lírica" acaba de empezar y que la labor no es fácil, "pues gran parte de los jóvenes que he encontrado son una especie de neofuturistas furibundos y los otros sacapuntas del simbolismo" (8). El simbolismo, naturalmente, ha de quedar atrás. En cuanto al futurismo, no es admitido por Huidobro, como iremos comprobando en estas cartas, y aquí surge un punto de disensión con los ultraístas.

El 22 de junio de ese año, Torre le informa de que la estela de difusión lograda por su tendencia lírica se prolonga cada día más longitudinalmente, pues Cansinos, una vez que ha captado del todo "las raigambres y surcos ramificativos de las novísimas directrices líricas, por usted trasladadas a España", y una vez que ha asimilado "algunos matices tegumentales de Apollinaire y de usted" (Huidobro 9), ha iniciado su hábil obra de polarización creacionista, continuando la serie de artículos de La Correspondencia de España con otros publicados en Cosmópolis, a los que se unen las traducciones de poemas huidobrianos escritos en francés que el propio Cansinos y quien firma esta carta han ofrecido en revistas del ultraísmo como Cervantes y Grecia. Cansinos, agrega Torre, ha reaccionado tras su primera actitud hostil y ha dado una formidable difusión a los libros de Huidobro. De hecho, su artículo de mayo en Cosmópolis está dedicado a Horizon carré, Poemas árticos y Ecuatorial. No obstante, Torre levanta las suspicacias del chileno al informarle de que no todo es altruismo en ese gesto mesiánico del crítico sevillano, pues ha aprovechado "el pasmo por usted suscitado" para promover, tras un manifiesto sintético "firmado por algunos de nosotros" (el manifiesto fundacional de Ultra que publican Cervantes, Grecia y Cosmópolis en enero, marzo y abril de 1919 respectivamente, aunque antes vio la luz en la prensa diaria), una "nueva escuela post-novecentista" a la que se ha denominado ultraísmo (11). Torre no pierde la ocasión de puntualizar que ese título aparece ya en uno de los originales suyos que entregó a Huidobro al marchar 
este de España. Evidencia con ello su ansia ultraísta, su afán por desplazar a Cansinos -algo semejante ocurrirá con el autor de Horizon carré- en el liderazgo de este movimiento (López Cobo 76-77; Alcantud 254), lo cual le lleva ya en Literaturas europeas de vanguardia a reivindicar que él es en realidad el inventor del término "ultraísmo" y a negar al maestro, quien, tras un momento de desconcierto, se repone y deviene el "más fervoroso turiferario" de Huidobro, "consagrándole estudios y apologías a granel" (Torre, Literaturas 40; Anderson 317).

En la carta que comentamos, Torre no deja de señalar que, a raíz de ese manifiesto, en el cual había una "lamentable promiscuidad de firmas", los adeptos al Ultra son innumerables, por lo que "los amigos de usted" (Huidobro 11) han debido hacer verdaderos esfuerzos para evitar las mixtificaciones, entre las cuales una de las más escandalosas ha sido la de Goy de Silva, aunque a la vez destacan las fieles "asimilaciones creacionistas" de Eugenio Montes y Pedro Garfias. De ello se deduce que Torre, en estos compases iniciales de su epistolario con Huidobro, no distingue con nitidez entre ultraísmo y creacionismo (el primero parece incluir al segundo), al menos no tanto como le gustaría al chileno. Incluso, le confiesa que "vengo de iniciar, tras mis veleidades conceptistas y neo-futuristas, un devenirismo esquemático basado en sus hallazgos creacionistas" (12). Torre declarándose creacionista y abandonando la fascinación futurista, que tan poco agrada a Huidobro: no deja de ser curioso si tenemos en cuenta que la disensión está a punto de sustituir a la admiración. Pues líneas más abajo le comunica que, con motivo de las traducciones de Cendrars, Apollinaire o Max Jacob que ha iniciado, ha escrito a Reverdy, quien le ha enviado sus poemas y la revista Nord-Sud "adjuntos a una carta indiscreta, necia y vanidosa, aludiéndole a usted como un élève de son école" (13). La reacción de Huidobro es contundente. El 3 de septiembre le responde que ese resurgimiento literario que hay en España no guarda relación con el creacionismo: "Es una lamentable confusión, pues todos esos poetas siguen siendo simbolistas" (14). No solo eso, sino que también cree advertir un empeño en Cansinos por posponerlo a Apollinaire y Reverdy. La caja de los truenos se ha abierto. Huidobro puntualiza a Torre que Apollinaire "no tiene nada que ver con nosotros", cosa que vería cualquiera con verdadero talento lírico, y que la de Reverdy es una afirmación gratuita: "Yo podría decir de él lo mismo, que es un discípulo mío, si no fuera porque considero su poesía demasiado mediocre" (14). Dispuesto a poner los puntos sobre las íes, afirma que es inútil querer cambiar las cosas y pretender que el francés sea anterior a él: "Reverdy es aún un poeta bastante descriptivo y 
rara vez tiene un verso que sea a medias creado. Mal puede ser anterior, pues ni aún hoy es creacionista" (14). Encontramos aquí, en germen, la semilla de la polémica del creacionismo y del cubismo, que estallará ya en el ámbito público dentro de unos meses.

Huidobro remacha este alegato pro domo sua mencionando su conferencia de 1916 en Buenos Aires, en la cual ya estaría contenido todo su credo estético tal y como lo practica en la actualidad. En conversación con Ángel Cruchaga publicada en agosto de este mismo año, 1919, el chileno declara que no pretende dar a entender que haya influenciado a Reverdy, cosa que sería tan falsa como que este le hubiera influenciado. Admite solo una "analogía espiritual", cierto fondo estético semejante entre ambos (Valcárcel 27), aunque son innegables la huella de la poética cubista y pura de Reverdy (Hubert; Jiménez Millán) en la escritura de Huidobro a partir de 1917 y la sintonía de la estética de ambos con el arte de Juan Gris ${ }^{6}$. Pero sigamos tejiendo los hilos de la relación epistolar entre Huidobro y Torre a partir de las noticias que en ella encontramos sobre el ultraísmo.

\section{LA OBSESIÓN POR LA PRIORIDAD}

Retornado a París, Huidobro expresa a Torre, el 30 de enero de 1920, su deseo de no saber nada de lo que pasa literariamente en España porque la mayoría de los ultraístas son unos arribistas que "desacreditan con sus confusiones y sus producciones ineptas la seriedad de algo que yo estoy obligado a defender más que nadie" (Huidobro 18). Su afán proselitista ha acabado en arrepentimiento: "Maldita mil veces la hora en que pasé por España y os revelé una parte de mi secreto tan querido y tan digno por su verdad y su pureza de mejor suerte y mayor respeto" (18). No cabe concluir sino que, a su entender, los vanguardistas españoles han deformado la estética creacionista (verdad, pureza, seriedad) que les ha revelado. Si unos lo han falsificado, otros han querido robarle lo que era suyo para ponerlo, comenta a Torre, en la cabeza de Apollinaire o Reverdy. Es una obvia alusión a Cansinos, quien en "La nueva lírica" (Cosmópolis, mayo de 1919) afirma que la paternidad

\footnotetext{
Véanse Diego, "Devoción" 89; Caracciolo Trejo; Rutter; Busto Ogden 95-98; Costa, "Juan Gris"; Soria Olmedo, "Cubismo" 39-40; Benko; Castro Morales 154-156; Anderson 268-278, 323-326.
} 
del creacionismo ha de quedar "indecisa" entre Huidobro y Reverdy, si no se le concede resueltamente a Apollinaire (Anderson 274, 320). En "Un gran poeta chileno: Vicente Huidobro y el creacionismo" (Cosmópolis, enero de 1919) había escrito más taxativamente que la paternidad de la tendencia traída por Huidobro a Madrid la compartió en París con otro singular poeta, Reverdy (Valcárcel 28; Díaz de Guereñu, Poetas 24).

El autor de Tour Eiffel insiste, sin embargo, en que todos los que le rodean en Francia, incluido Reverdy ("un mal discípulo mío"), siguen siendo poetas descriptivos, con lo cual "queda demostrado quién ha sido el primero" (Huidobro 19). Puede decirse que la obsesión por la prioridad y la angustia de las influencias, en el sentido de Bloom, lo atenazan. A Torre, molesto con la actitud del chileno hacia los ultraístas, trata de hacerle ver que "toda la gente que sabe dice que yo soy el único que no es descriptivo ni anecdótico y en el cual todo es creado por el poeta", cosa que viene sosteniendo "desde el año 1915". Además, confiesa estar "harto de los pick-pockets literarios", de los "ladrones de paternidad", y acusa ya sin ambages a Torre y Cansinos de "haberme presentado al público español como habiendo logrado en España lo que ya existía en Francia" (20). No solo no aclaran las cosas, sino que dejan cundir, quizás con agrado, la confusión y el caos. Y así pide a Torre que, si ve a Cansinos, le diga de su parte que se resigne ante la verdad y no busque más padrinos al creacionismo, porque no los encontrará ni en Mallarmé ni en nadie. Esta carta acaba al filo de la ruptura: "No quiero saber nada con la estupidez bullanguera, llámese dadaísmo, futurismo o ultraísmo. Soy felizmente más serio" (21).

El 18 de febrero, Torre contesta lamentándose de esta carta "llena de gritos y acusaciones" en la que Huidobro ha llevado su "inmotivado encono con nosotros" hasta un límite ofensivo. El autor de Poemas árticos, arguye el joven ultraísta, parece haber olvidado la cordial acogida que ha tenido en España, donde su obra ha sido expandida por "nuestro esfuerzo y nuestro entusiasmo", sin ocultar nunca su "figura inductora" (Huidobro 21). Particularmente, agrega, acogió con efusión su lírica y defendió su estética aun arrastrando anatemas e inculpaciones, pero admite haberse puesto en contacto con otras personalidades de vanguardia a fin de traducir y comentar sus obras. En este sentido, se ha limitado a escribir aisladamente sobre Apollinaire y Reverdy, sin relacionarlos con el chileno: "Solo a Cansinos puede usted hacerle estas imputaciones, reconociendo al mismo tiempo que usted, con sus antiguas evocaciones a Reverdy, y él, con su deficiencia informativa, son las únicas causas promotoras" (22). 
La actitud de Torre variará sustancialmente en este punto de las conexiones con Reverdy y otros poetas cubistas, como veremos, cuando estalle la polémica creacionismo/cubismo (Laffranque; Cano Ballesta), hoy considerada estéril (Curieses 226) por cuanto el creacionismo es el nombre que da Huidobro a su personal versión de la poesía cubista ${ }^{7}$. Por ahora aprovecha para desplazar astutamente a Cansinos y para mostrar una adhesión total a Huidobro, con quien comparte su afirmación de ser el único poeta creacionista y de haber intuido su estética ya en 1915, antes de llegar a París. No obstante, sin medir hasta qué punto puede contrariar al chileno, matiza que este no querrá "aparecer desprendido de ciertas inevitables conexiones, ni impedir que penetren en España, al margen de la suya, otras tendencias líricas de vanguardia" (Huidobro 22). Torre sigue fiel a su concepción del ultraísmo como un movimiento integrador de distintas tendencias vanguardistas. Con todo, se presenta ante Huidobro, que no tiene más fe que la creacionista, con una actitud de disidente con relación al núcleo ultraísta y a Cansinos, lo que le ha convertido en un "heresiarca" que mantiene "una total independencia aun en mi equidistancia radical cubista" (22). Anuncia una pronta época de selección y cristalización y se ofrece a regentar en España una "revista de purificación" que Huidobro podría dirigir desde París, no sin cometer la torpeza, a ojos del chileno, de preguntarle, además de por los cuadros de Gris, si ha presenciado la lectura de manifiestos dadaístas en el Salón de los Independientes que ha tenido lugar un par de semanas antes.

El 24 de febrero, Huidobro vuelve a la carga confesando a Torre que casi todos sus amigos españoles le escriben advirtiéndole que no solo Cansinos, también él, han querido presentarlo al público como uno de tantos: “¿Pero es que no ha comprendido usted toda la pureza de mi obra y de mi vida?" (Huidobro 32). Para reprocharle a renglón seguido: “¿No comprende usted que cuando yo grito y protesto no hay en ello ni una sola gota de arribismo sino la desesperación del artista sincero que ve que sin querer ha sembrado el caos y la locura?". El chileno se desespera ante los ultraístas españoles en nombre de la pureza del arte y clama contra esa locura y ese caos que deforman "lo que más puedo amar”. Mal puede haber querido él impedir el conocimiento en España de Reverdy, Cocteau, Dermée o Tzara y aparecer desprendido de estas conexiones cuando ha puesto en contacto a su corresponsal con estos autores. Si ha hablado de Reverdy, ello prueba la confianza y la seguridad que tenía 
en su verdad y cuán lejos estaba de pensar en las "torcidas interpretaciones" de los sembradores de calumnias y "tristes pick-pockets literarios" (33). En cuanto a Dadá, nada sabe ni quiere saber de esos "aprovechadores que empezaron acercándose a nosotros". Descubre en Torre una "inclinación fatal hacia todos esos grupos equívocos y falsos innovadores", sin darse cuenta de que va a caer en el abismo: "Esos individuos, como allá los ultraístas, son nuestros enemigos porque ellos son el bluff y nosotros somos la verdad" (35). Tanto Gris como Picasso, tanto Lipchitz como él están empeñados en una lucha terrible contra esos farceurs de los dadaístas.

Torre le contesta el 8 de marzo argumentando que nunca ha dudado de su sinceridad estética y de la pureza innovadora de su lírica. Huidobro debe persuadirse de la irradiación y del triunfo, por fortuna restringido, de su obra en España: "Las mixtificaciones de Cansinos Assens no han servido a obstaculizar el florecimiento de puros seguidores, o tácitos iluminados, que, al margen del ultraísmo vilipendiado, sabrán remontarse y cantar con voz propia" (Huidobro 37). Por lo demás, las conexiones con otros poetas d'avant-garde han de preocuparle poco si no rebasan los límites de una coordinación de contemporaneidad, porque así, en el contraste de tendencias, resaltará aún más la "absoluta originalidad" del creacionismo. Aclara que solo aludía a analogías teóricas y más bien de técnica con los poetas cubistas, sin vulnerar la esencia auténtica de la poesía del chileno. Y comprende, en fin, que le desagrade Dadá, lo mismo que a todos los que forman el núcleo del cubismo pictórico y literario, frente al que las desarticulaciones dadaístas "solo son alaridos de una disidencia heterodoxa, y en definitiva un anhelo bolcheviki [sic] y pueril" (37). No hay en él, matiza, atracción hacia esos grupos equívocos, sino curiosidad y una sugestión epidérmicamente informativa que le llevará a conocerlos y a "situarme conscientemente" (38).

Parece claro que Torre ha captado el sentido constructivo del cubismo y del creacionismo, frente al sentido destructivo del dadaísmo o la modernolatría futurista. Si Huidobro proclama en el número inicial de su revista Création (1921) que ya ha terminado la época de destrucción y ha comenzado la de construcción ${ }^{8}$, Diego afirma en su conferencia "La poesía nueva" (1919) que el ultraísmo es negacionista por su ruptura con el pasado y el creacionismo afirmacionista y clásico, clásico per se, como dirá años después (Diego, 
"Vicente Huidobro" 187)9. El propio Torre, avanzando ya de forma clara en Literaturas europeas de vanguardia hacia el retorno al orden en el que se embarca la "joven literatura" o el $27^{10}$, deja atrás las veleidades dadaístas para apostar por ese programa constructivo y modernizador de la segunda vanguardia española fundamentado en el cubismo y en la noción clave de forma ${ }^{11}$.

A Diego, que escribe a Huidobro tras animarle Torre a ello, el chileno le explica en carta del 28 de abril de 1920 el origen del creacionismo, dándole detalles sobre cómo surge en su conferencia de 1916 en Buenos Aires y sobre cómo ha protestado contra la injusticia de algunos escritores españoles que han querido sembrar la confusión relacionando a Apollinaire, Jacob y Reverdy con su estética, cuando los dos primeros son verdaderos poetas, aunque de otra generación, y el último "ni siquiera es poeta como son los dos anteriores" (Huidobro 55). Recordando una vez más el célebre prefacio a Horizón carré ("Rien d'anecdotique ni de descriptif"), sentencia que los tres son poetas anecdóticos y descriptivos "y yo soy todo lo contrario: nada de anécdota ni de descripción" (55). Por eso le parece grotesco pretender, como Cansinos, que la paternidad del creacionismo no está clara aún entre él y Reverdy, si este "aun hoy todavía no logra hacer un solo poema creacionista" (56). No es que sea un vanidoso ridículo queriendo ser el primero en términos cronológicos, puntualiza al final de esta misiva, sino que no puede tolerar el "afán de falsear los hechos" (59). Al igual que Torre en un comienzo, Diego cierra filas en torno a Huidobro y el 17 de mayo le responde que siempre ha dudado del valor actual de la poesía de Reverdy y de otros franceses y no franceses que son presentados como modelos de creacionismo, y que siempre ha sostenido que "es usted y solo usted el verdadero clásico del nuevo arte" y que sus poemas "son autónomos y nada tienen que ver con dadaístas, expresionistas, etc." (60). La diferencia entre Torre y Diego estribará en que, cuando explote la polémica cubismo/creacionismo y repercuta en la ruptura entre ultraístas y creacionistas, aquel acabará tomando partido por Ultra y este por Huidobro, como también hará Larrea.

9 No pasa inadvertida la afirmación de Diego (La poesía 73, 80) a Díaz de Guereñu, "Prólogo" 33-34 y Anderson 502.

10 Cfr. Soria Olmedo, Vanguardismo 143-145; Carmona 92-93; Calvo Carilla XL-LIII; Alcantud 428-430.

11 Sobre esta cuestión: Soria Olmedo, "El valor”; Salaün 41-43; García, El Veintisiete, Cartografias, Los compromisos; Alcantud 133. 
Muy poco antes de que explote esa polémica con la aparición el 30 de junio de 1920 en El Liberal de la entrevista de Gómez Carrillo a Reverdy, donde este acusa al chileno de haber antedatado un libro - El espejo de agua, presuntamente publicado en 1916- para hacer creer que, lejos de ser él quien imitaba la nueva estética cubista, los demás lo imitaban a él (Gómez Carrillo 126), Huidobro envía a Diego una carta, fechada el 7 de junio, en la cual le informa de que en L'Esprit Nouveau -cuyo primer número aparecerá en agosto- va a publicar un artículo sobre la literatura de lengua española actual en el que habla algo del origen del creacionismo (Huidobro 61). Aquí considera el ultraísmo "une dégradation ou une mauvaise compréhension du créationnisme" 12 . Encauzado ya hacia el creacionismo -el 15 de julio aparece en Grecia su "Intencionario", donde afirma que el ultraísmo es voluntad y el creacionismo afirmación estética, y se posiciona junto a "los creacionistas por ahora" (Diego, "Intencionario" 172)-, el 6 de julio el cántabro expresa a Huidobro, como ya ha hecho Torre, su deseo de que aparezca una revista pura, "absoluta de poetas creacionistas, o a lo más limítrofes", porque Grecia, "promiscuable y contradictoria", no puede satisfacerles (Huidobro 62).

Dos días después, Torre comunica al autor de Horizon carré que, cuando ya creía rota la amistad de ambos, un reciente hecho, la publicación del artículo de Gómez Carrillo, le obliga a superar todo enojo y a acudir en su defensa literaria. Las calumnias de Reverdy, que se proclama el único iniciador del creacionismo, le han producido indignación, hasta el punto de haber redactado un varapalo contra el francés que se publicará en Grecia (julio de 1920), concretamente en la sección "Panorama ultraísta", y del que adelanta a Huidobro un fragmento. También le informa de una larga carta que ha escrito a Gómez Carrillo, director de Cosmópolis, en cuyo número de agosto aparecerá publicada ya convertida en el artículo "La poesía creacionista y la pugna entre sus progenitores". Como explica a Huidobro, en este artículo coteja los poemas del francés y del chileno, examina sus respectivos postulados estéticos y concluye afirmando que "no obstante ciertas coincidencias teóricas de usted con él y de ambos con Max Jacob, el creacionismo de usted es anterior y más logrado" (Huidobro 65). La posición de Torre en este asunto será siempre la misma, señalando las coincidencias teóricas de Huidobro con el cubismo (Apollinaire, Jacob, Reverdy, Dermée,

12 Tal y como recuerdan Costa, "Del modernismo" 265; Díaz de Guereñu, "Ultraístas" 174; Morelli, “Introducción” LV; Alcantud 246. 
Cocteau, Albert-Birot e incluso un pintor como Braque) a la hora de buscar un arte autónomo, de creación y no de imitación, y reconociendo todo lo más los mayores logros poéticos del autor de Ecuatorial, cosa claramente insuficiente para este $^{13}$, quien en lo tocante a la querelle con el antiguo compañero de Nord-Sud tendrá sus defensores académicos, detractores a la vez de Torre (Bajarlía, "El creacionismo" y "La leyenda"). En esta carta del 8 de julio de 1920, el joven ultraísta hace saber a Huidobro que, desde ahora, Grecia excluye toda traducción de Reverdy, cuya desfachatez también ha indignado a Cansinos, Montes, Bacarisse y otros. Todo esto prueba, a juicio de Torre, la injusticia y el apresuramiento de las acusaciones huidobrianas contra los ultraístas, y en particular contra él, que ha activado "mis réplicas defensivas de su prestigio literario" (Huidobro 66).

\section{EL DIVORCIO DE SENDEROS}

El 15 de julio de 1920, Huidobro anuncia a Diego que está escribiendo un artículo feroz contra Reverdy (Huidobro 66). Piensa publicarlo en Grecia, cuyo director, Isaac del Vando-Villar, le ha mostrado su solidaridad ante el ataque del francés y le ha ofrecido su revista para replicar. Finalmente, esta autodefensa no ve la luz en la revista sevillana, que la estima demasiado larga y difamatoria y pide al chileno que contribuya con los gastos de impresión del número. No debe olvidarse, además, el juicio peyorativo sobre el ultraísmo que vierte Huidobro poco después en L'Esprit Nouveau. La ruptura con los ultraístas es un hecho. El 14 de agosto, Torre le escribe haciendo mención explícita de ese artículo, que por supuesto reprueba. Al mismo tiempo, le comunica que ya no es oportuno publicar su réplica a Reverdy en Grecia y que él ha hecho bastante con publicar en el número de julio su protesta (se refiere al mencionado "Panorama ultraísta"). La cuestión, precisa Torre al comienzo de esta querelle con Huidobro, ahora es más personal que literaria y el chileno ha de solventar particularmente su pugna con el francés, "sin nuestra solidarización” (Huidobro 69) ${ }^{14}$. Torre se sirve incluso del sarcasmo

14 Para la mencionada querelle: García, "La polémica"; Morelli, "Introducción" XLIX-LVII; Bernal Salgado, "Creacionismo epistolar" 26. 
cuando felicita a Huidobro por su "perspicacia y lealtad" al prescindir de los ultraístas, "que tanto y tan desinteresadamente lo han exaltado" (70), en su revista Création. Los episodios posteriores de esta querelle son bien conocidos: en septiembre de 1923, Torre publica en la revista coruñesa Alfar el artículo "Los verdaderos antecedentes líricos del creacionismo en Vicente Huidobro", donde considera al uruguayo Herrera y Reissig un incógnito precursor creacionista (Bernal Salgado, El ultraísmo 37); en abril de 1924, también en Alfar, Huidobro responde con el artículo "Al fin se descubre mi maestro" (ya publicado en febrero, en el suplemento castellano de Création), donde acusa a Torre de haberle copiado en Hélices (1923) imágenes de su acervo; y Torre contesta a su vez en "Rasgos polémicos. Réplica a Vicente Huidobro", publicado en el mismo número de Alfar (Valcárcel 36-40; Alcantud 381-384).

El 16 de agosto, Huidobro aprovecha la tirantez de sus relaciones con Vando-Villar para comunicar a Diego que le ha hablado mal de él en su último viaje a Madrid: "Según yo creo es porque usted se ha declarado creacionista" (Huidobro 71). Vando publicará en septiembre, en Grecia, un "Panorama ultraísta" anónimo donde da cuenta de que los ultraístas han roto toda clase de vínculos con "Huidobro el ególatra". Consciente de la lealtad de Diego, el chileno se extiende sobre el director de Grecia señalando que "el ser sostenedor y jefe del ultraísmo no es una honra, sino el más gran deshonor que conozco, pues no sé si exista hoy en poesía nada más idiota, menos original y consciente que el ultraísmo", "una cosa al alcance de cualquier cerebro inculto" (Huidobro 72; Morelli, "Introducción” XXX). Empleando los mismos términos que ya usaba en una de sus cartas a Torre, estima necesario que los creacionistas españoles vean dónde está la verdad y dónde el bluff. Un día después responde a Torre señalando que es ridículo en su pluma ese tono de tristes reconvenciones, puesto que fue él quien no tuvo inconveniente en conducirle de la mano por el arte moderno e iniciarle en el creacionismo, cuando su corresponsal llegaba a él tembloroso y con los ojos muy abiertos de curiosidad y entusiasmo, que ahora abre por el contrario a la "política del arte" (75). Huidobro le recrimina una nota publicada en su sección de Grecia "Mis amigos y yo", en julio de 1920, donde Torre habla de la lucha del chileno por la supremacía contra todo precursor rival y adjudica primogénitos más persuadidos al ideario cubista: “¿Quiere usted explicarme a mí el cubismo que yo le expliqué a usted y que usted no ha jamás comprendido?" (75). 
Paradójicamente, Huidobro reconoce de este modo su deuda con el cubismo. A la vez, dice no comprender por qué Torre se espanta de su opinión sobre el ultraísmo si, como vimos, le comentaba que Cansinos se había aprovechado de su paso por Madrid para lanzar esta escuela nueva, en cuyo manifiesto se producía una promiscuidad de firmas intolerable: "Ahora salta usted en defensa de lo que fue el primero en atacar. ¿Tiene usted miedo a su jefe el señor del Vando-Villar?" (Huidobro 76). En cuanto a la exclusión de los ultraístas en Création, todos "son muy malos poetas, muy viejos y sin nada que valga la pena", si bien advierte que no conoce ni a Garfias ni a Montes. Y muy ilustrativo de su distancia del futurismo, ya clara en las primeras cartas a Torre, es lo que añade después: "El ultraísmo es el futurismo en tonto y cuando me piden mi opinión para una revista como es el caso de L'Esprit Nouveau yo doy mi opinión franca, sincera y no la opinión de los demás" (76). Todo el mundo que conoce la materia y que en París recibe Grecia, y alude en particular al crítico de arte Maurice Raynal, está de acuerdo en que en el ultraísmo no hay nada. La desesperación del artista que busca la creación pura aflora cuando sentencia: "Haced buenos poemas y seremos amigos"; o bien: "Dejad a un lado la política y daos por completo a vuestro arte" (77). De hecho, indica que cuanto poeta serio y de verdadero valer aparezca en España encontrará en él apoyo y una franca acogida; su revista queda abierta esperando. La política que se hace en todas partes permite la entrada al templo a todos los mercaderes astutos y maquiavélicos: "No, Guillermo, mil veces no. Soy demasiado serio, amo mucho el arte para no gritar clara la verdad en su honor y aplaudir confusiones" (77).

La respuesta de Torre llega el 29 de agosto, en una prolija carta. Para empezar, aclara a Huidobro que las amicales recriminaciones que se permitió hacerle se debieron al dolor de constatar su infidelidad "para con nosotros los ultraístas". No debe extrañarle, continúa diciendo, que él se incluya en ese "nosotros", pues si bien ha censurado a Ultra ha sido siempre combatiendo a ciertos rezagados, "pero nunca contra la intención superadora del grupo, que marca la causa de mi inicial y decidida adhesión a él" (Huidobro 78). Por eso le resulta necesario deshacer el error y la "torva obcecación" en que el chileno se encuentra frente al ultraísmo. A partir de aquí, haciendo una historia de su relación con este movimiento, le explica cómo venía desde 1917 rotulando como ultraístas algunas de sus composiciones, sin el propósito de formar escuela, queriendo solo condensar en ese "vocablo-lema" su intención disidente y superadora. A últimos de 1918, Cansinos le anuncia su intención de formar un grupo de jóvenes ultramodernistas $y$, aunque no era partidario 
de ello, como la tendencia que aquel esgrimía coincidía con la suya, no pudo negarse a cooperar, sobre todo porque él había sido, "indeliberadamente", el primero en propulsarla. Como vemos, la pugna con Cansinos por la paternidad de Ultra es pertinaz.

Continuando con su relato personal, Torre detalla cómo poco después le sorprendió ver en varios periódicos el manifiesto del ultraísmo con su firma, no pareciéndole mal en última instancia la "confraternidad avanzativa" que pudiese hallar en el grupo. En abril de 1919, comenzó a colaborar en Grecia, revista en la que, como en Cervantes y Cosmópolis, la obra de Huidobro ha tenido eco "merced a nuestro entusiasmo" y a la generosidad de Cansinos, que el chileno no ha sabido apreciar: “¿Para qué insistir recordando las reiteradas exaltaciones y la alta categoría que le hemos adjudicado, mientras usted se revolvía airado, en una inexplicable y desagradable acometividad con los ultraístas?" (Huidobro 80). Todo conduce a sostener, añade, que la actitud de soberbia del chileno no guarda paralelismo con la que los ultraístas han tenido hasta ahora con él. Por otra parte, el ultraísmo no es ni mucho menos lo que Huidobro cree: "Padece usted un estrabismo" (80).

No es que trate de hacer la apología del grupo ni que tema a Vando-Villar, puntualiza Torre a continuación. Se define como "perfectamente libre" y detalla cómo en algunas etapas ha permanecido alejado del ultraísmo o cómo, en los orígenes de este, al asumir Cansinos la "jerarquía visible", afirmó su individualismo y se declaró "ultraísta tangencial". Hoy, el ultraísmo no es un movimiento unilateral, cada cual esgrime su personalidad y el único lazo que une a espíritus muy diversos es "la intención superatriz y rebasadora" contenida en la palabra Ultra. Por lo demás: "No es el futurismo en tonto, como usted precipitadamente dice, ni el creacionismo en listo" (Huidobro 81). En él coexisten creacionistas, futuristas, cubistas y "hasta ultraístas puros": "Es el vértice de fusión e irradiación adonde abocan aferentes los esfuerzos pugnaces de los distintos lucíferos que hoy polarizan sus rayos innovadores. Es una especie de avant-garde española, que por primera vez vibra contemporáneamente a la nueva literatura mundial" (81). Aquí adelanta planteamientos que se repiten casi con las mismas palabras en Literaturas europeas de vanguardia (Torre, Literaturas 37 ).

Torre continúa en esta misiva su pliego de descargos. No existe en los ultraístas la menor intención política o arribista. Los juicios sobre el grupo que Huidobro le transmite desde París difieren por completo de los que él posee, emitidos por personalidades de la misma índole. Cansinos no ha intentado aprovecharse del creacionismo. Torre venía cultivando el ultraísmo 
con anterioridad, no le debe nada al maestro sevillano, y por eso "me creo paradójicamente en la obligación de rehabilitarle" (Huidobro 82). En la pugna del chileno con Reverdy, ha mostrado una "firme lealtad amical", si bien la imparcialidad crítica le ha llevado a evidenciar las coincidencias teóricas de Huidobro con todo el grupo cubista, "que viene formulando desde 1912, por boca de Apollinaire, los apotegmas precursores del arte de creación, y no de imitación o evocación" (82). En efecto, Apollinaire, tal y como subraya Torre en un trabajo bastante posterior (Apollinaire 88-93), incide en sus meditaciones estéticas sobre los pintores cubistas en que ya no imitan la naturaleza, sino que hacen un arte de concepción que se eleva a la creación (Apollinaire 30; Matamoro 29). Parece que Huidobro conoció estos planteamientos antes de llegar a París (Pizarro 235).

Aunque también ha marcado en su artículo sobre la pugna de los progenitores del creacionismo las diferencias con Reverdy, sigue diciendo Torre en esta carta, duda haber satisfecho las "exigencias absolutistas y egolátricas" del chileno (Huidobro 82). Frente a la lealtad que le ha guardado el grupo ultraísta, Huidobro ha prescindido de él en su revista, hecho representativo de su comportamiento con quienes lo han sostenido. La ruptura es un hecho: "El divorcio de senderos está marcado, y ya jamás le abrumarán nuestras recriminaciones. Se acabaron los elogios del mismo modo que las supuestas censuras y confusiones" (83). No obstante, le hace saber que al tener noticia de que el director de Grecia, Vando-Villar, pensaba dar cuenta de esta ruptura con frases agresivas, le ha rogado que atenúe sus enojos, aun mostrándole su conformidad con la absoluta distanciación en lo sucesivo. Todavía arguye Torre en esta sustanciosa carta que no hay en él la menor inclinación al bluff. Si en ocasiones se ha mostrado, por ejemplo, “juglaresco dadaizante", prevé "el vértice serio y elevado adonde abocaré con mi modalidad el día de mañana" (84). Además, le hace saber que tiene en Grecia más fuerza de la que Huidobro supone, lo mismo para impedir que se le combata (alusión a Vando-Villar) que para desechar sus cuartillas sobre un pleito (contra Reverdy) ya solventado y "cuyo epílogo pertenece a otro escenario" (84). Como colofón a su misiva, Torre repite que jamás hace política, que no comparte los exclusivismos del chileno, que mantiene la afirmación de su personalidad independiente dentro del ultraísmo y que se cree capacitado para hablar tanto del cubismo como de otras modalidades del arte nuevo. Hasta aquí la relación epistolar de Huidobro y Torre en lo concerniente a Ultra. 


\section{TORRE Y DIEGO: LA FIJACIÓN DE ACTITUDES}

El 5 de noviembre de 1920 es Diego quien escribe a Huidobro informándole de que en Grecia han publicado unas líneas contra él -alude al mencionado "Panorama ultraísta" de Vando-Villar- "con falsedades tan burdas sobre el asunto creacionismo-ultraísmo que solo podría colaborar en esa revista a trueque de que me publicasen una aclaración haciendo constar mi protesta por esas insidias" (Huidobro 86). En efecto, allí se afirma que el creacionismo se considera en Francia un brote del ultraísmo ${ }^{15}$. Poco antes, el 27 de octubre, Torre ha escrito a Diego una carta, dada a conocer por Neira (109-110), donde le expone que se está en el umbral de una nueva etapa ultraísta y conviene fijar las actitudes personales. Vando-Villar le ha comentado el presunto alejamiento del santanderino respecto de "nuestro núcleo" y su "posición intermedia en el caso Grecia-Huidobro", determinada por este último. Le explica que lo que suscitó el divorcio de los ultraístas con el chileno fue una razón de ética literaria y de dignidad personal, pues mientras Cansinos y él han venido exaltando su personalidad y dándole "categoría de precursor al frente de nuestro movimiento", Huidobro les ha combatido desde París y los ha excluido de su revista. En su ruptura con Grecia, toda la razón está del lado de Vando, quien se negó a insertar la réplica a Gómez Carrillo, pues no podía convertir la revista en un libelo difamatorio.

Asimismo, Torre pregunta a Diego si ha leído su artículo de Cosmópolis sobre la primogenitura del creacionismo y la pugna Reverdy/Huidobro, dilucidada por él al demostrar que la modalidad creacionista es una derivación del cubismo literario, si bien reconociendo que sus "realizaciones poemáticas" son superiores, constatación generosa que no habrá agradecido Huidobro en su "egolatrismo absorbente". Tanto este artículo como los dos siguientes que piensa publicar en Cosmópolis servirán a Diego para comprobar la verdadera filiación del chileno y "sus absurdas obcecaciones contra el ultraísmo", reaccionando así a sus falsedades malévolas. En opinión de Torre, todos deben concentrarse en Grecia, de la que han sido eliminadas las firmas equívocas, y es hora de combatir los comentarios falsos, como el de Espina en España, "desenfocado y deleznable". En efecto, Espina ha sentenciado que el ultraísmo es apenas una orientación y un buen deseo, que le falta talento y literariamente 
no pasa con él nada (Barrera López, El ultraísmo 229). Para finalizar, Torre anuncia a Diego que con el próximo número de Grecia recibirá su "Manifiesto ultraísta vertical" (Soria Olmedo, Las vanguardias 35-36), que el cántabro podría glosar en España u otra revista, "fijando paralelamente su actitud".

Consumada su biografía ultraísta ma non troppo (Bernal Salgado, La biografía 13), el cántabro no tiene inconveniente en fijar su actitud y lo hace en una carta a Torre del 9 de noviembre donde expresa el disgusto que le ha causado el asunto Grecia-Huidobro, porque, al margen de la conducta de este, siempre irreprochable con él, no le parece lícito "falsear a sabiendas" los hechos, como ha ocurrido en el "Panorama ultraísta" citado: "Históricamente, el ultraísmo es posterior al creacionismo (se ha confesado siempre). Huidobro ha influido en España muchísimo más que lo que luego los ultraístas hayan podido influir en él" (Neira 111). Su posición, añade, está explicada: es creacionista, como reflejan sus artículos "Posibilidades creacionistas" (Cervantes, octubre de 1919) y el mencionado "Intencionario", donde defiende, y así lo proclama también en esta carta, que se puede simultanear el creacionismo con la poesía tradicional, ya que son planos distintos. Finalmente, indica que reanudará su colaboración con Grecia si antes le dejan aclarar su independencia y su protesta contra el "Panorama" de marras, y que no cree que esta actitud divergente impida que todos juntos "sigamos luchando por ideales que están por encima de estas diferencias".

Lo cierto, sin embargo, es que esos artículos de Cosmópolis a los que se refiere Torre en su carta acaban haciendo gala de una ortodoxia ultraísta que lleva a tachar a Diego de "creacionista epigónico" (Neira 112). Más tarde, al reseñar Imagen en Cosmópolis (julio de 1922), censura que la sección del libro así titulada, "Imagen", revela "la influencia invasora que, desde los albores del ultraísmo, empezó a ejercer Huidobro sobre Diego con su teorías creacionistas", marcando con ello netamente "su filiación y su epigonía huidobristas" (Barrera López, "La prosa" 93; García, "Gerardo Diego" 12). En Literaturas europeas de vanguardia, advierte que, si en un principio el cántabro otorgó una adhesión total al ultraísmo, compartiendo su credo sustancial, después, bajo la "influencia absorbente" de su mentor Huidobro, prefirió rehuir el contacto y aceptar la etiqueta de creacionista (Torre, Literaturas 52). Y en agosto de 1927, en la revista bonaerense Martín Fierro, reprocha a Diego su "máscara jánica de dos personalidades radicalmente antípodas y, a mi juicio, dignamente inconciliables", su juego incansable de "espejos dúplices", su "juglarismo ambidextro" en definitiva, y sin entender su heterocronismo y su integración de tradición y vanguardia, 
condena el "maniqueísmo poéticamente sacrílego" en que se obstina (García, "Gerardo Diego" 18-21) ${ }^{16}$.

Volviendo a la correspondencia de Diego con Huidobro, conviene resaltar que el 13 de marzo de 1921 le manifiesta cómo se encuentra cada vez más aislado del mundo literario, aunque le comprometieron los ultraístas para la velada que se celebró el pasado enero en la sala de fiestas Parisiana, donde leyó versos y unas cuartillas de estética creacionista: "Mauricio Bacarisse hizo el resumen, y tuvo para usted un recuerdo y un homenaje de justicia como abanderado espiritual nuestro" (Huidobro 91). El 19 de marzo, Huidobro le contesta señalando que el cántabro no se ha equivocado al declararse creacionista, pues todo el mundo va hacia ellos mientras el ultraísmo se hunde en el ridículo. A la vez, le ruega pedir a Tomás Luque, Humberto Rivas y José Rivas Panedas las cartas en las que les expuso las razones por las cuales "yo no puedo tomar parte en un movimiento que me parece retroceder en vez de avanzar y que solo siembra el caos puesto que empieza por declarar que aceptan todo lo nuevo y todas las escuelas" (92). Por si fuera poco, escribe lo siguiente: "Algún día podrá usted cantar victoria por alejarse de ellos, que nacieron de nosotros sin comprendernos" (93).

Tras conocerse personalmente el 19 de diciembre de 1921 con motivo de la conferencia que Huidobro da en el Ateneo de Madrid, organizada por el propio Diego (Costa, "Posibilidades" 12), el chileno le participa el 14 de enero del año siguiente la impresión de que ha hallado en él y en Larrea lo que posiblemente no ha encontrado en sus anteriores pasos por España, una comprensión íntegra para su obra y una noble simpatía, "exenta de toda adulación y recelo" (Huidobro 101). A vuelta de correo, el 29 de enero, Huidobro espera que Diego haya comprendido después de conocerlo cómo nunca podrá tomar en serio el ultraísmo, pues nada detesta más que "los elementos esenciales que lo constituyen: lo pintoresco, la fantasía y el dinamismo de maquinaria. Todo falsa modernidad, lado externo y no interior", trompe l'oeil y "tropicalismo meridional" representado en Europa ayer por Italia y hoy por España: "Futuristas y ultraístas y estos todavía hijos espurios,

16 Sobre estas peculiaridades de la poética de Diego llama la atención Bernal Salgado, "La ejemplaridad" 123-125, "Gerardo Diego: heterocronismo", "Gerardo Diego: aproximaciones" 59-61, "El creacionismo" 3, "Gerardo Diego y las vanguardias". Puede consultarse, asimismo, Pérez Bazo, "Donde dije" 136. 
inferiores a aquellos" (Huidobro 103) ${ }^{17}$. No se olvide que, ya en las cartas a Torre, Huidobro ataca el futurismo, uno de los componentes del cóctel ultraísta ${ }^{18}$. En la mencionada conversación con Cruchaga afirma que, cuando llegó a la capital francesa, muchos de los jóvenes que deseaban escapar del molde simbolista habían caído en algo mucho peor: el futurismo (Anderson 255); incluso, postula que en la revista Nord-Sud, que fundó con Reverdy en 1917, ha nacido la tendencia más seria desde el simbolismo: "Nosotros no hemos pretendido como los futuristas hacer el arte de mañana, ni como los neo-simbolistas interpretar el arte pretérito, nos contentamos simplemente con hacer el arte de hoy" (272).

Otro de los ingredientes de ese cóctel es Dadá. A este respecto, el 30 de abril de 1922 Diego da noticia a Huidobro de que ha dictado una conferencia sobre estética y poética en el Ateneo de Madrid donde ha hablado valientemente del vacío que se ha hecho a los libros y poetas creacionistas, siendo intolerable que la crítica española informe de las "cabriolas dadaístas" y no se haya enterado de los espléndidos Poemas árticos ni con cuatro años de retraso (Huidobro 110). Poco después, el 21 de junio, le hace saber que los ultraístas han desaparecido al parecer para siempre, porque ya no sale ninguna revista ni han publicado libros; Índice, la revista juanramoniana, da a conocer cosas de poetas nuevos, algunos muy finos como Lorca y Alonso (está asomando la "joven literatura"): "Con ello el ultraísmo puede darse por definitivamente fenecido" (116). El 7 de octubre le confiesa que ha leído las "tonterías" de Torre en su reseña de Imagen: “me llama cándido y no sé qué cosa más por haberme dejado engañar" (131).

Meses más tarde, el 27 de enero de 1923, vuelven las referencias al ultraísmo en la correspondencia de Huidobro y Diego. Este ha publicado un poema en la nueva revista Horizonte, que dirige Garfías, y "es lo mejor que tenemos, aunque deje bastante que desear". Al menos: "Es una revista sin compromiso ista, la palabra Ultra está prohibida en ella" (Huidobro 144). En esta misma carta informa al chileno que Vando-Villar ha estado por Uruguay y Argentina dando "absurdas conferencias sobre ultraísmo" y que Humberto Rivas ha marchado a Cuba por asuntos no literarios, de modo que, insiste, el

17 Recogen estos duros juicios sobre el ultraísmo Díaz de Guereñu, "Ultraístas" 174 y Poetas 37; Morelli, "Introducción” XXVIII; Alcantud 327.

18 La atinada imagen del "cóctel" es empleada por Bonet, "Baedeker" 32 y Las cosas 15 . 
ultraísmo puede darse por fenecido. Solo queda de superviviente Torre, que prepara sus Hélices, un libro falso de tan puramente ultraísta, un compendio de prácticas de vanguardia más que un libro de poemas, como ha dicho la crítica, que sin embargo ha roto con la idea tópica de que el ultraísmo se manifestó básicamente en las revistas y muy poco en libros ${ }^{19}$. El 9 de mayo da cuenta a Huidobro de que ya se ha publicado ese libro "verdaderamente grotesco", que con el tiempo verá como un "extraordinario documento de época" (Diego, "Guillermo de Torre" 345): "Ha tenido un gran éxito de risa" (Huidobro 146).

Cuatro días después, Torre escribe a Diego reprochándole que está enterado de su opinión sobre Hélices y que hubiera agradecido se la hubiese manifestado directa y privadamente "en vez de propalarla sinuosamente" (García, "Gerardo Diego" 15). Él siempre ha expuesto con claridad sus divergencias de criterio, sin acritud, pero con energía, por ejemplo cuando habló de Imagen, o en una reciente interview humorística que, por lo tanto, Diego no debe tomar literalmente. Se refiere a "Visita del interviewer ignotus al autor de Hélices", publicada en abril, donde llama al cántabro "poeta ambiguo, de transición, que tiene absorbida su probable personalidad por la influencia magnética que sobre él ejerce el chileno Huidobro" (15). En esta misma carta, Torre aclara que no tiene una actitud unilateral sobre la lírica de vanguardia y que se esfuerza por aceptar todas las direcciones convergentes, pareciéndole que el creacionismo de Huidobro no es sino una derivación de las teorías del cubismo literario, como demuestra en un capítulo "de mi libro crítico en prensa" (Literaturas europeas de vanguardia). Con todo, no cree que esa fórmula seguida por Diego pueda asumir el monopolio de todas las posibilidades estéticas actuales, pues el mismo Diego dijo - Torre alude a una frase de "Intencionario" (Diego, "Intencionario" 172)- que el creacionismo era un camino más que una meta.

A partir de 1923, las alusiones al ultraísmo se diluyen en las cartas cruzadas de Huidobro, Torre y Diego. En enero de 1924, Huidobro pregunta a Diego si ha leído el artículo de Torre "Los verdaderos antecedentes líricos del creacionismo en Vicente Huidobro", donde dice que, teniendo el cántabro filiación con el chileno, la tiene a su vez con Reverdy, el más descriptivo

19 Sobre Hélices, véanse López de Abiada 103; Bernal Salgado, "Los frutos" 119120; Bonet, Las cosas 30-31; Alcantud 360-361. Sobre los poemarios del ultraísmo: Barrera López, "Los libros" 50. 
de los poetas de hoy, "el polo opuesto a mi poesía y a la de todos nosotros" (Huidobro 159). El 9 de febrero notifica a Diego que Création acaba de salir y que en su suplemento castellano contesta al artículo citado de Torre "como se lo merece" (165).

Si su desesperación de artista, si su pureza lírica constructiva y su sólida teoría poética chocaron con la indefinición, la simple búsqueda de lo nuevo, el caos y la política literaria del grupo Ultra, Huidobro encontró en dos "prófugos ultraístas" (Calvo Carilla XL), Diego y Larrea, dos discípulos dignos de su escuela. Muy pronto, ya el 22 de junio de 1919, Larrea escribe a Diego una carta, muy citada por la crítica, donde señala que, si dentro del ultraísmo no contemplamos el creacionismo, el primero es "únicamente un deseo, mal comprendido por espíritus mediocres, sin más razón de existir que el odio a lo pasado, aunque ellos no hayan dado una nota verdaderamente artística, nueva" (Diego y Larrea 249) ${ }^{20}$. Los ultraístas, continúa diciendo, son los antípodas del creacionismo, que no admite la descripción, lo exterior y sencillo en el sistema: "Para comprender el ultraísmo se necesitaría un poeta. Hoy por hoy, hasta que no venga, es vacuo y artificial". En cambio, el creacionismo tiene un admirable poeta, Huidobro, y además "una estética más o menos limitada y una grandísima razón de ser” (249).

Han pasado cien años del nacimiento del ultraísmo, del movimiento que inició la vanguardia española y acabó con los restos de la estética modernista, pero cuya relevancia artística e historiográfica, más allá de la función iconoclasta y preparadora de caminos que le asignaron algunos poetas del 27 como Gerardo Diego y Dámaso Alonso, solo últimamente ha comenzado a ser puesta de relieve por la crítica especializada. Las cartas que se dirigen Huidobro, Torre y Diego contribuyen de forma decisiva a iluminar, como hemos venido señalando hasta aquí, diversos puntos que afectan directamente a la mejor comprensión del grupo Ultra y a su exacta ubicación en la historia de la vanguardia española y de sus relaciones con la vanguardia internacional. Esta correspondencia cruzada revela el papel de Huidobro en la conformación del movimiento ultraísta, las deudas del creacionismo con el cubismo, las tensiones en el campo literario del momento entre ultraístas y creacionistas, las estrategias de Huidobro por concentrar todo el capital simbólico ante sus admiradores españoles, la apertura de estos a las distintas novedades sin otorgar

20 Citan esta carta Bernal Salgado, La biografía 24; Díaz de Guereñu, "Ultraístas" 178; Anderson 483. 
especial preeminencia a la estética defendida por el autor de Horizon carré, las fricciones en el seno del movimiento español por asumir su liderazgo, que llevan a Torre a reconocer el magisterio de Cansinos Assens, pero también a desplazarlo, como ocurre a la larga con el del propio Huidobro, o bien la fidelidad creacionista de Gerardo Diego una vez que descubre la poca consistencia de unos poetas que solo parecen agarrarse a la superstición de lo nuevo y proclamar la necesidad de ir más allá.

Todas estas cuestiones hasta aquí desgranadas nos permiten concluir que la desesperación de Huidobro como artista no obedece únicamente a razones estéticas, a la supuesta mayor pureza de su creacionismo frente a la presunta ambición, confusiones y poca seriedad de los ultraístas. El chileno exige en todo momento reconocimiento de su liderazgo y sumisión a su papel anunciador de la verdadera vanguardia (la creacionista, frente al dadaísmo y el futurismo por él despreciados) entre las filas de sus jóvenes seguidores españoles o incluso entre maestros del Ultra como Cansinos Assens. Por lo que se refiere a Torre, es una figura molesta para Huidobro desde el punto en que, con su ingenuidad entusiasta, aunque muy bien informada, muestra las innegables deudas de la teoría poética creacionista con el cubismo de Reverdy. Parece claro que cubismo y creacionismo son dos nombres de la misma cosa, aunque lógicamente las ideas que fundamentan el poema tengan matices diferenciales en cada caso y quizás calidades distintas. De la admiración inicial se pasa a la franca reserva y a la ruptura abierta cuando el autor de Tour Eiffel, llevado por su egolatría y su voluntad de convertirse en un auténtico "poeta fuerte", desprecia a los ultraístas, que acaban vetándolo e impidiendo que utilice sus revistas para la mencionada campaña de autoafirmación. Resulta fundamental, con todo, tener en cuenta que las desavenencias entre Huidobro y Reverdy, la pugna entre creacionismo y cubismo, son la antesala de la distancia que acaba abriéndose entre ultraístas y creacionistas. Torre se rebela contra la tiranía personalista de Huidobro y trata de depurar el campo de la primera vanguardia, llamando al orden incluso a un poeta mayor como Gerardo Diego, que ha abandonado los conatos ultraístas porque ha visto con lucidez el carácter constructivo o clásico del creacionismo, la posibilidad de simultanear tradición y vanguardia a la vez que la conveniencia de no instalarse sin más en esta última. No se equivoca ni mucho menos, a tenor de lo que va a representar enseguida la llegada de la "joven literatura". En efecto, el grupo del 27 asimila las lecciones de la vanguardia con menos inmediatez y mucha más distancia que los ultraístas. Sin un poeta mayor, víctima de su eclecticismo y de su simple afán por la novedad, el ultraísmo 
es muy pronto rebasado por los llamados a nacionalizar la vanguardia en España. Ha provocado, eso sí, la desesperación de un artista como Huidobro, que no supo o no quiso apreciar el decisivo papel de este movimiento en la conformación de la vanguardia histórica española y en la apertura de caminos para la gran poesía que vino poco después, en la segunda mitad de los años veinte. Las cartas aquí analizadas muestran que aún queda por espigar e interpretar buena parte de la jugosa y abundante información que nos han venido ofreciendo durante los últimos años los epistolarios de la llamada "Edad de Plata" de la cultura y la literatura españolas.

\section{BIBLIOGRAFÍA}

Alcantud, Victoriano. Hacedores de imágenes. Propuestas estéticas de las primeras vanguardias en España (1918-1925). Granada: Comares, 2014.

Anderson, Andrew A. El momento ultraísta. Orígenes, fundación y lanzamiento de un movimiento de vanguardia. Madrid/Frankfurt am Main: Iberoamericana/Vervuert, 2017.

Apollinaire, Guillaume. Meditaciones estéticas. Los pintores cubistas. Madrid: Visor, 1994.

Aullón de Haro, Pedro. La modernidad poética, la vanguardia y el creacionismo. Ed. Javier Pérez Bazo. Málaga: Anejos de Analecta Malacitana, 2000.

Bajarlía, Juan-Jacobo. "El creacionismo en Huidobro y Reverdy". Costa, ed. 1975. 145-149. "La leyenda negra contra Huidobro". Costa, ed. 1975. 167-176.

Barrera López, José María. El ultraismo en Sevilla. Historia y textos. Sevilla: Alfar, 1987.

"La prosa ensayística de Diego sobre Ultra". Memoria y literatura. Estudios sobre la prosa de Gerardo Diego. Ed. Francisco Javier Díez de Revenga y José Luis Bernal Salgado. Cáceres: Universidad de Extremadura, 2003. 79-95.

"Los libros del ultraísmo (Un capítulo pendiente en el estudio de la primera vanguardia)". Geh hin und lerne. Homenaje al profesor Klaus Wagner. Coord. Piedad Bolaños Donoso, Aurora Domínguez Guzmán y Mercedes de los Reyes Peña. Vol. 1. Sevilla: Universidad de Sevilla, 2007. 49-87.

Benko, Susana. Vicente Huidobro y el cubismo. México: FCE, 1993.

Bernal Salgado, José Luis. La biografía ultraísta de Gerardo Diego. Cáceres: Universidad de Extremadura, 1987.

El ultraísmo. ¿Historia de un fracaso? Cáceres: Universidad de Extremadura, 1988. “La ejemplaridad vanguardista de Gerardo Diego". Morelli, coord. 1991. 121-135. 1993. ed. Gerardo Diego y la vanguardia hispánica. Cáceres: Universidad de Extremadura,

"Los frutos de la vanguardia histórica". Voces de vanguardia. Ed. Fidel López Criado. La Coruña: Universidad de La Coruña, 1995. 97-122. 
“Gerardo Diego: heterocronismo y visión del mundo". Ínsula 597-598 (1996): 6-8. "Gerardo Diego: aproximaciones a su teoría poética y visión del mundo". En círculos de lumbre. Estudios sobre Gerardo Diego. Ed. Francisco Javier Díez de Revenga y Mariano de Paco. Murcia: CajaMurcia, 1997. 49-64. "Poesía creacionista". Pérez Bazo, ed. 1998. 161-180. "El creacionismo como tradición”. Ínsula 642 (2000): 3-5.

"Gerardo Diego y las vanguardias. La polimusía de un poeta: entre la tradición y la vanguardia". Gerardo Diego y las vanguardias europeas. Cuaderno adrede 2. Santander: Fundación Gerardo Diego, 2006. 13-33. “Creacionismo epistolar”. Ínsula 760 (2010): 24-26.

Bonet, Juan Manuel. "Baedeker del ultraísmo". El ultraísmo y las artes plásticas. Dir. Juan Manuel Bonet y Carlos Pérez. Valencia: IVAM, 1996. 9-58. ed. Las cosas se han roto. Antología de la poesía ultraísta. Sevilla: Fundación José Manuel Lara, 2012.

Busto Ogden, Estrella. El creacionismo de Vicente Huidobro en sus relaciones con la estética cubista. Madrid: Playor, 1983.

Calvo Carilla, José Luis. "Guillermo de Torre: protagonista e historiador de la vanguardia". Torre 2002. XIII-CL.

Cano Ballesta, Juan. "Sobre cubismo y creacionismo poético (Ecos de una controversia)". Ojáncano 1 (1988): 5-13.

Caracciolo Trejo, Enrique. "Huidobro y el cubismo". La poesía de Vicente Huidobro y la vanguardia. Madrid: Gredos, 1974. 43-61.

Carmona, Eugenio. "Los años del arte nuevo. La generación del 27 y las artes plásticas". El universo creador del 27. Literatura, pintura, música y cine. Ed. Cristóbal Cuevas García. Málaga: Publicaciones del Congreso de Literatura Española Contemporánea, 1997. 85-111.

Castro Morales, Belén. "Los horizontes abiertos del cubismo: Vicente Huidobro y Pablo Picasso". Anales de Literatura Chilena 9 (2008): 149-167.

Costa, René de. "Del modernismo a la vanguardia: el creacionismo pre-polémico". Hispanic Review 43. 3 (1975): 261-274.

ed. Vicente Huidobro y el creacionismo. Madrid: Taurus, 1975.

Huidobro: los oficios de un poeta. México: Fondo de Cultura Económica, 1984.

“Juan Gris y la poesía”. Juan Gris (1887-1927). Dir. Gary Tinterow. Madrid: Ministerio de Cultura/Banco de Bilbao, 1985. 73-92.

"Posibilidades creacionistas: Gerardo Diego". Bernal Salgado, ed. 1993. 11-24.

Curieses, Óscar. “Al horitaña de la montazonte. Procedimientos cubistas en Altazor de Vicente Huidobro". Escritura e Imagen 4 (2008): 225-247.

Díaz de Guereñu, Juan Manuel. "Ultraístas y creacionistas: midiendo las distancias”. Bernal Salgado, ed. 1993. 157-180.

Poetas creacionistas españoles. Málaga: Centro Cultural Generación del 27, 2001. "Prólogo". Diego 2014. 9-51. 
Díaz de Guereñu, Juan Manuel y José Luis Bernal Salgado. “Introducción”. Diego y Larrea 2017. XV-XLV.

Diego, Gerardo. "Devoción y meditación de Juan Gris". Gerardo Diego. Obras completas. Prosa. Ed. Francisco Javier Díez de Revenga. Vol. 5. Madrid: Alfaguara, 1997. 82-95. "Intencionario". Gerardo Diego. Obras completas. Prosa. Ed. José Luis Bernal Salgado. Vol. 6. Madrid: Alfaguara, 2000.171-173. "Vicente Huidobro (1893-1948)". Diego 2000. 181-189.

"Guillermo de Torre". Diego 2000. 344-346. Obras completas. Prosa. Ed. José Luis Bernal Salgado. Vol. 8. Madrid: Alfaguara, 2000. La poesía nueva. Ed. Juan Manuel Díaz de Guereñu. Madrid: Fundación Gerardo Diego/Publicaciones de la Residencia de Estudiantes, 2014.

Diego, Gerardo y Juan Larrea. Epistolario 1916-1980. Ed. Juan Manuel Díaz de Guereñu y José Luis Bernal Salgado. Madrid: Fundación Gerardo Diego/Publicaciones de la Residencia de Estudiantes, 2017.

Fuentes Florido, Francisco, ed. Poesías y poética del ultraismo. Antología. Barcelona: Mitre, 1989.

García, Carlos, ed. Rafael Cansinos Assens/Guillermo de Torre. Correspondencia 1916-1955. Madrid/Franflurt am Main: Iberoamericana/Vervuert, 2004.

"La polémica Huidobro-Torre a la luz de correspondencias inéditas (Cansinos, Vando-Villar, Reyes, Ramón)". Nel segno di Picasso. Linguaggio della modernità dal mito di Guernica agli epistolari dell'avanguardia spagnola. Ed. Gabriele Morelli y Margherita Bernard. Milán, Viennepierre Edizioni, 2005. 121-142.

“Gerardo Diego y Guillermo de Torre". Huarte de San Juan. Filología y Didáctica de la Lengua 10 (2008): 9-24.

García, Miguel Ángel. El Veintisiete en vanguardia. Valencia: Pre-Textos, 2001.

Cartografías del compromiso. Vanguardia e ideología en los poetas del 27. Barcelona: Calambur, 2016.

Los compromisos de la joven literatura. Años veinte y treinta en España. Barcelona: Anthropos, 2018.

Goic, Cedomil. "Vicente Huidobro en España". Viajeros, diplomáticos y exiliados. Escritores hispanoamericanos en España (1914-1939). Ed. Carmen de Mora y Alfonso García Morales. Bruselas, Peter Lang, 2012, Vol. 2. 67-82.

Gómez Carrillo, Enrique. "El cubismo y su estética”. Costa, ed. 1975. 125-128.

Hubert, Étienne-Alain. "Pierre Reverdy et la poésie plastique de son temps". Europe 638-639 (1982): 109-117.

Huidobro, Vicente. Epistolario. Correspondencia con Gerardo Diego, Juan Larrea y Guillermo de Torre 1918-1947. Ed. Gabriele Morelli con la colaboración de Carlos García. Madrid: Publicaciones de la Residencia de Estudiantes, 2008.

Jiménez Millán, Antonio. "La poética de Reverdy”. Analecta Malacitana 6.1 (1983): 21-40.

Laffranque, Marie. "Aux sources de la poésie espagnole contemporaine: la querelle du créationnisme”. Bulletin Hispanique 64 bis (1962): 479-489. 
López de Abiada, José Manuel. "Guillermo de Torre: versificador y teórico ultraísta, cronista y definidor de la vanguardia". La vanguardia europea en el contexto latinoamericano. Ed. Harald Wentzlaff-Eggebert. Frankfurt am Main: Vervuert Verlag, 1991. 79-103.

López Cobo, Azucena. "El ansia ultraísta de Guillermo de Torre". Analecta Malacitana 31. 1 (2008): 61-77.

Martínez Ferrer, Héctor. Ultraísmo, creacionismo, surrealismo. Análisis textual. Málaga: Anejos de Analecta Malacitana, 1999.

Matamoro, Blas. “Apollinaire, Picasso y el cubismo poético". Cuadernos Hispanoamericanos 492 (1991): 29-38.

Morelli, Gabriele. "Huidobro en la vanguardia española”. Morelli, coord. 1991. 101-119. coord. Treinta años de vanguardia española. Sevilla: El Carro de la Nieve, 1991. "Introducción". Huidobro 2008. XI-LXXVI.

Neira, Julio. Trasluz de vida. Doce escorzos de Gerardo Diego. Barcelona: Anthropos, 2013.

Pérez Bazo, Javier. "Donde dije creación digo Diego (Sobre teoría y praxis literaria creacionistas)".

Gerardo Diego, poeta mayor de Cantabria. Ed. Rafael Gómez de Tudanca, Rosa Fernández

Lera y Andrés del Rey Sayagués. Santander: Sociedad Menéndez Pelayo, 1996. 127-152.

“El ultraísmo". Pérez Bazo, ed. 1998. 101-160.

ed. La vanguardia en España. Arte y literatura. París: CRIC \& OPHRYS, 1998.

Pizarro, Ana. "El creacionismo de Vicente Huidobro y sus orígenes”. Costa, ed. 1975. 229-248.

Rutter, Frank. "La estética cubista en Horizon carré de Vicente Huidobro". Bulletin Hispanique 80. 1-2 (1978): 123-133.

Salaün, Serge. "Vanguardias estéticas en España". Nuevos caminos en la investigación de los años 20 en España. Coord. Harald Wentzlaff-Eggebert. Tubinga: Max Niemeyer Verlag, 1998. 37-46.

Soria Olmedo, Andrés. Vanguardismo y crítica literaria en España. Madrid: Istmo, 1988. "Cubismo y creacionismo: matices del gris". Boletín de la Fundación Federico García Lorca 9 (1991): 39-49.

"El valor de las imágenes: el 27 y las artes plásticas". Ínsula 612 (1997): 23-24. ed. Las vanguardias y la generación del 27. Antología. Madrid: Visor, 2007.

Torre, Guillermo de. Apollinaire y las teorías del cubismo. Barcelona: Edhasa, 1967. Ultraísmo, existencialismo y objetivismo en literatura. Madrid: Guadarrama, 1968. “La poesía creacionista y la pugna entre sus progenitores”. Costa, ed. 1975. 129-143. "La polémica del creacionismo: Huidobro y Reverdy". Costa, ed. 1975. 151-165. Literaturas europeas de vanguardia. Ed. José Luis Calvo Carilla. Pamplona: Urgoiti, 2002.

Urrutia, Jorge. "El movimiento ultraísta". Morelli, coord. 1991. 89-100.

Valcárcel, Eva. "Vicente Huidobro y el creacionismo en España". Huidobro homenaje 18931993. Coord. Eva Valcárcel. La Coruña: Universidad de La Coruña, 1995. 11-52.

Videla, Gloria. El ultraísmo. Estudios sobre movimientos poéticos de vanguardia en España. $2^{\mathrm{a}}$ ed. Madrid: Gredos, 1971. 